\title{
The Analysis Of Civil Servant's Drafting Needs On The Regional Secretariat Of Central Sumba Regency East Nusa Tenggara Province
}

\author{
Oktavianus Sabarua \\ State Administration of Magister Program's Collage Student \\ Manado State University
}

\section{Mentor}

\author{
Dr. Thelma Wawointana, M.Si and Dr. Jetty E. H. Mokat, M.Si
}

DOI: 10.29322/IJSRP.10.06.2020.p10280

http://dx.doi.org/10.29322/IJSRP.10.06.2020.p10280

\begin{abstract}
The Civil Servant's drafting needs is a must for all government institution to carry out the number and quality of employees following the needs of the organization. But in reality, every government institution still experiences a limited number of employees. This study aims to determine and understand how the stages of the analysis of Civil Servant's drafting needs in the scope of the Central Sumba District Secretariat and the determination of the Civil Servant's needs nationally by the central government. The used research method is qualitative by collecting data through interviews, observation, and documentation.

The result showed that the Civil Servant's drafting needs in the scope of the Central Sumba District Secretariat were carried out based on the stages of analysis which included collecting data and information, evaluating employee needs, compiling employees reallocation plans, and preparing additional plans for new employee formation. The analysis result of Civil Servant's drafting needs shows that there is still a shortage of employees when compared to the total needs of employees based on the workload of the government institution, so it necessary to propose the addition of new employee formation. And in determining the Civil Servant's drafting needs process is not entirely based on proposals submitted by local governments because of the determination of the needs of Civil Servants us entirely under the authority of the central government without any intervention from the local government. Therefore, efforts that can be made to overcome the shortcomings of Civil Servants are to recruit/procure Government Employees with a Work Agreement.
\end{abstract}

Keywords: Drafting needs, additional plan formation, needs determination.

\subsection{Background}

\section{INTRODUCTION}

A good government system is realized through the implementation of the Bureaucracy Reform which is essentially an effort to make fundamental reforms and changes to the system of governance, especially in the aspects of the organization, management, and management of Human Resources Apparatus. Bureaucratic Reform is a strategic step to build a State Civil Service that is useful and effective in carrying out the tasks of government, development, and service to the community. The aim is to face and take advantage of opportunities from the changing world and technological developments that are changing so fast. Human Resources can be said to be quality if they know (knowledge), ability (ability), skills (skills), and attitude (attitude) are good at work, including a high willingness to give the best effort and effort for the organization where it is placed.

Quality Human Resources will be able to be maximized through a process commonly known as human resource management. Human resource management (human resources management) is a management activity that includes the utilization, development, assessment, provision of rewards for humans as individual members of the organization, (Samsuddin, 2006: 22). Government Regulation Number 11 the Year 2017 concerning Management of Civil Servants is one of the implementing regulations of Act Number 5 of 2014 concerning State Civil Apparatus, which specifically regulates the process of implementing civil servant management. In Article 1 paragraph (1) it is explained that "Management of Civil Servants is the management of civil servants to produce civil servants who are professional, have basic values, professional ethics, are free from political intervention, free from corrupt practices, collusion, and nepotism".

The first focus of the implementation of civil servant management based on these Government Regulations is the "formulation and determination of needs" as stated in Article 2 letter (a). In the elucidation of Article 56 paragraph (1) of Law Number 5, the Year 2014 states that "Preparation of the needs of civil servants is an analysis of the needs of the number, types, and status of civil servants needed to carry out the main tasks effectively and efficiently to support the workload of Government Agencies". The aim is to realize the number and quality of civil servants following the needs of the organization and to guarantee a proportional distribution of civil servants. 
The Regional Secretariat of Central Sumba Regency as one of the Regional Apparatus, following the mandate of the Act is obliged to make the requirements for civil servants. Based on data obtained from the 2018 Institutional Data and Civil Service Data Recapitulation Reports, the needs of civil servants for the Regional Secretariat are 51 (fifty-one) people. However, based on the Central Sumba Regent's Announcement Number: BKPP.800 / 1004 / 53.17 / IX / 2018, September 19, 2018, concerning Acceptance of Civil Apparatus of the Central Sumba District Government in 2018, the number of stipulations on the needs of civil servants in 2018 was 331 (three hundred thirty) one) detailing 175 (one hundred seventy-five) people for teachers, 126 (one hundred twenty-six) people for health workers, and 30 (thirty) people for technical staff. From the formation of the technical staff, only 1 (one) person is allocated to meet the needs of civil servants within the scope of the Regional Secretariat, namely for the position of Electronic Procurement Services Manager in the work unit of the Goods and Services Procurement Section. This shows the gap between the needs of civil servants submitted by local governments with the needs of civil servants determined by the central government. Based on these conditions it is felt necessary to conduct a study of the stages of the analysis of the preparation of civil servant needs, as well as in their application relating to the determination of civil servant needs nationally.

\subsection{Formulation of the Problem}

Based on the background of the problem above, the authors formulated the problem as follows:

1. How is the preparation of the needs of Civil Servants (PNS) in the Regional Secretariat of Central Sumba Regency?

2. How is the application of the results of the preparation of the needs of Civil Servants (PNS) in the Regional Secretariat of Central Sumba Regency?

\subsection{Research purposes}

In connection with the problems that have been formulated above, the objectives of this study are:

1. To find out and analyze the preparation of the needs of Civil Servants (PNS) at the Regional Secretariat of Central Sumba Regency;

2. To find out and analyze the application of the results of the preparation of the needs of Civil Servants (PNS) at the Regional Secretariat of Central Sumba Regency.

\subsection{Benefit of Research}

1. Benefits of Theotiris

It can enrich concepts or theories in the development of science, especially in the field of Human Resource Management and the development of government organizations in general.

2. Practical benefits

Can provide meaningful input for the Central Sumba District Government, particularly at the Regional Secretariat and stakeholders as well as the wider community regarding Human Resource Management, especially in formulating the needs of Civil Servants.

\subsection{Management Theory}

\section{THEORETICAL REVIEW}

Management is defined as the science and art of regulating the process of utilizing Human Resources and other resources effectively and efficiently to achieve certain goals (Hasibuan, 2007: 2). Management theory can be understood as a social process and social figure. As a social process, management theory is the process of how an organization can run effectively and efficiently. As a process, management activities consist of several management functions. According to G.R. Terry in his book entitled Principles of Management, management functions include:
a. Planning
b. Organizing
c. Actuating
d. Controlling

(Terry, 2006:77-78)

Based on the above management functions, it can be explained that planning is a process of making decisions regarding desires that contains implementation guidelines to achieve organizational goals. Organizing is the process of determining, grouping, and organizing various types of activities based on what is needed by the organization to achieve its goals. Mobilization is the process of moving each subordinate to carry out an activity that will become a common goal. Supervision is the process of observing various kinds of implementation of organizational activities to ensure that all work can go according to a predetermined plan. 


\subsection{Human Resource Management}

I Komang Ardana (2012: 5) argues that "human resource management is the process of human empowerment as a human workforce so that all of its physical and psychological potentials function optimally to achieve goals". Furthermore, Marwansyah (2014: 3) states that "human resource management is the utilization of human resources within the organization, which is done through the functions of human resource planning, recruitment and selection, human resource development, planning and career development, compensation and welfare, safety and health at work and industrial relations. "

Based on some of these opinions it can be concluded that Human Resource Management is a science and art that regulates the relationships and roles of employees or employees to be able to realize organizational goals effectively and efficiently. Human Resource Management is engaged to move and manage human resources in an organization to be able to think and act following organizational expectations.

Melayu S.P. Hasibuan (2011: 250) states that the general objectives of human resource management are as follows:

1. Determine the quality and quantity of employees who will fill all positions in the company;

2. Ensuring the availability of workers now and in the future;

3. Avoid misunderstandings in management and overlap in the performance of tasks;

4. Facilitate coordination so that work productivity increases; and

5. Avoiding employee shortcomings or strengths.

Based on this opinion, it can be said that human resource management is very important in managing the implementation of organizational tasks, especially in the effort to compile and determine employee needs, placement, and development, and strive for employee welfare so that organizational climate can be maintained well.

\subsection{Preparation of Needs of Civil Servants}

Preparation of the needs of Civil Servants is an obligation for government agencies both central and regional agencies. Preparation of needs is carried out systematically and is a strategic process to predict the conditions of the number of Human Resources, types, and qualifications, as well as the desired skills and competencies in the future. Law Number 5 of 2014 concerning State Civil Apparatus, Article 56 paragraph (1) states that "every Government Agency is required to draw up the number and type of requirements of civil servants based on a job analysis and workload analysis". Furthermore, Government Regulation Number 11 the Year 2017 concerning Management of Civil Servants Article 5 paragraph (3) states that "the preparation of civil servant needs as referred to in paragraph (1) must support the achievement of the objectives of Government Agencies". The preparation of civil servant needs is carried out for 5 years and is detailed each year based on the priority needs listed in the strategic plan.

Based on the priority needs of current employees and to support national development priorities, the government is currently more focused on compiling employee needs to support compulsory programs related to basic services, namely education, health, and other administrative staff who can support the process of carrying out the core tasks of government but still consider the availability of the budget and the potential of each region. Therefore, the formulation of these needs becomes very important and obligatory to be carried out based on the applicable mechanism. The stages of analyzing the needs of civil servants according to the Regulation of the Head of the Civil Service Agency Number 19 of 2011 concerning General Guidelines for the Preparation of Civil Servants' Needs include:

1. Data and information collection;

2. Evaluate employee needs;

3. Compilation of employee reallocation plans; and

4. Formulation of additional plans for the formation of new employees.

In collecting data and information, the data collected includes the number of employees per unit of the organizational unit of the regional agency, position information, position maps, strategic plans, regional profiles, geographical conditions, and regional development potential. Whereas in evaluating the needs of employees is done by comparing the amount of inventory with the needs of employees for structural and functional positions, to obtain the number of advantages and disadvantages of employees for structural and functional positions. Next compile a plan for reallocation of employees in organizational units that are excess employees to be placed in organizational units that are lacking employees. And finally, compile additional plans for the formation of new employees for organizational units that lack staff.

\section{RESEARCH METHODS}




\subsection{Research Approach}

The approach used in this research is a qualitative approach which through this approach will obtain rich data and indepth information about the issues or problems raised and want to be solved. To understand the uniqueness of the object under study, understand the process of social interaction that is complex and always changing, and efforts to understand the feelings of people who often change or ensure the truth of data, it is necessary to do it through a qualitative approach. Therefore, this research is aimed at understanding the preparation and application of the results of the preparation of civil servant needs at the Regional Secretariat of Central Sumba Regency.

\subsection{Research Focus}

The focus of the study was determined based on the level of importance and urgency of the problem to be solved and the factors of limited energy, time, and cost. Therefore, this research is focused on the stages of analysis of the preparation of civil servant needs within the scope of the Regional Secretariat, and the determination of the needs of civil servants nationally by the central government. An employee needs analysis is a method for knowing the number of employees in an organizational unit based on workload, and comparing the needs of employees with supplies to find out the real needs of employees. Whereas the determination of the needs of civil servants nationally by the central government is entirely guided by or based on proposals submitted by the Regional Personnel Management Officers.

\subsection{Research Site}

The location chosen for conducting this research is the work unit of the Organization Section at the Central Sumba District Secretariat. The reason is that the Organization Section, based on the provisions of the Statutory Regulations is a work unit that coordinates the process of drafting the needs of Civil Servants.

\subsection{Data Source}

Data collection uses primary and secondary sources. Primary sources are data sources that directly provide data to data collectors. As for the primary data sources are the Head of Organization Section, Head of Institutional and Position Analysis Subdivision, Staff at the Organization Section, and several members of the PNS needs preparation team. While secondary sources are sources that do not directly provide data to data collectors. As for the sources of secondary data in the form of laws and regulations, official documents in the form of letters, institutional and staffing data, territorial data, and other data that have relevance in the process of preparing civil servant needs.

\subsection{Data Collection Technique}

In this study using data collection techniques namely participatory observation, in-depth interviews, and documentation. In observation, researchers are involved in carrying out evaluations of employee needs, as well as the preparation of additional plans for the formation of new employees. Whereas in conducting interviews the researchers asked questions freely using everyday language and dialogue to create a flexible atmosphere but still adhere to the interview guidelines that had been made. Then in the study of documentation, documents or data that are examined include institutional data and staffing data, job analysis and workload analysis, position maps, regional profiles, and regulations relating to the preparation and determination of civil servant needs.

\subsection{Data Analysis}

In this study, researchers used Miles and Huberman's Model data analysis, which included: (1) Data Reduction, which summarizes, selects and chooses the main points, focuses on important matters, looks for themes and patterns; (2) Presentation of Data (Data Display), carried out so that the reduction data can be well organized and arranged in a relationship pattern making it easier for readers to understand research data; and (3) Conclusion Drawing (verification), wherein qualitative research, conclusions may be able to answer the problem formulation but also not answer the problem formulation because it depends on the evidence from the results of the study.

\section{RESULTS AND DISCUSSION}




\subsection{Preparing the Needs of Civil Servants in the Regional Secretariat of Central Sumba Regency}

The success of an organization in realizing the vision and mission that has been determined is very dependent on the quality of existing Human Resources (HR), starting from the leadership level to the lowest level, namely the implementing staff. Human Resources are people who are mobilized and employed in an organization or company as a source of movers, thinkers, and planners to achieve the goals of the organization (Elbadiansyah, 2019: 2). This definition explains that if HR is not managed properly and correctly to be able to work together an organization can't run well and optimally in line with expectations. Therefore we need a good management process.

Human resource management is the utilization of human resources in the organization, which is carried out through the functions of human resource planning, recruitment and selection, human resource development, career planning and development, compensation and welfare, work safety and health and industrial relations (Marwansyah, 2014: 3). Another opinion defines human resource management is a series of human resource management activities that focus on practices and policies, as well as management functions to achieve organizational goals (Yunarsih and Suwanto, 2008: 3).

This explanation, implies that Human Resource Management is a process of regulating and utilizing human resources in an organization to achieve the stated goals. In this case Human Resources (PNS) become subjects that must be empowered properly through the HR planning function which is carried out through the preparation and determination of PNS needs to produce quality PNS and be able to realize the organization's vision and mission.

Government Regulation Number 11 the Year 2017 concerning Management of Civil Servants is one of the implementing regulations of Act Number 5 of 2014 concerning State Civil Apparatus, which specifically regulates the process of implementing civil servant management. The first focus of the implementation of civil servant management based on these Government Regulations is the "formulation and determination of needs" as stated in Article 2 letter (a). And in Article 5 paragraph (1) it is explained that "every government agency is required to draw up the needs for the number and type of PNS positions based on the job analysis and workload analysis".

The preparation of civil servant needs is an analysis of the needs of the number, types, and status of civil servants needed to carry out the main tasks effectively and efficiently to support the workload of government agencies. While the main purpose of the preparation of civil servant needs is to realize the number and quality of civil servants following the needs of the organization and to ensure a proportional distribution of civil servants.

The stages of the analysis of the preparation of civil servants according to the Regulation of the Head of the Civil Service Agency Number 19 of 2011 concerning General Guidelines for the Preparation of Civil Servants' Needs include:

\section{Data and information collection}

Collecting data and information is a stage to collect data on structural positions consisting of high Pratama leadership positions, administrative positions, and executive positions. But in this case it is more focused on executive positions because it relates to the determination of civil servant needs. The data collected includes the number of employees per unit of the organizational unit of the regional agency, position information, position maps, strategic plans, regional profiles, geographical conditions, and the potential for regional development.

Based on research data, there is a gap between the number of employees available and the number of employee needs based on the workload of government agencies. This harms efforts to improve service quality and the achievement of organizational goals that have been set.

\section{Evaluate employee needs}

The preparation of employee reallocation plans is carried out on organizational units that are overstaffed to be placed on organizational units that are understaffed. This needs to be done to realize the proportional distribution of employees in support of the workload of government agencies.

However, the results of the study found that the reallocation of employees could not be carried out given the limited number of available employees so that this harmed efforts to improve the quality of service and the achievement of the organization's vision and mission.

\section{Compilation of employee reallocation plans}

The preparation of employee reallocation plans is carried out on organizational units that are overstaffed to be placed on organizational units that are understaffed. This needs to be done to realize the proportional distribution of employees in support of the workload of government agencies.

However, the results of the study found that the reallocation of employees could not be carried out given the limited number of available employees so that this harmed efforts to improve the quality of service and the achievement of the organization's vision and mission.

\section{Formulation of additional plans for the formation of new employees}


The preparation of additional plans for the formation of new employees is done for organizational units that lack staff. This is done as part of an effort to realize the availability of the number of employees to meet the needs of employees in each work unit. The hope is that the proposal can be accommodated or accepted to be determined to be the needs of civil servants nationally by the central government.

Therefore it can be said that based on the results of the analysis of the preparation of civil servant needs at the Regional Secretariat found problems where the number of staff availability does not match the needs of the organization. This is evidenced by the data on the sum of civil servant needs that can be seen in the table below:

Table

Recapitulation of Data on PNS Needs at the Regional Secretariat

\begin{tabular}{|c|c|c|c|c|}
\hline No & Position (echelon) & Amount of need & Real conditions & Deficiency \\
\hline 1. & Regional Secretary (II a) & 1 & 1 & - \\
\hline 2. & Specialist staff (II b) & 3 & 3 & - \\
\hline \multirow[t]{4}{*}{3.} & Assistant for Governance and Social Welfare (II b) & 1 & - & 1 \\
\hline & - $\quad$ Head of Division (III a) & 3 & 3 & - \\
\hline & - $\quad$ Head of subsection (IV a) & 9 & 9 & - \\
\hline & - $\quad$ Implementers / Staff (V) & 33 & 10 & 23 \\
\hline \multirow[t]{4}{*}{4.} & Assistant for Economy (II b) & 1 & 1 & - \\
\hline & - $\quad$ Head of Division (III a) & 3 & 3 & - \\
\hline & - $\quad$ Head of subsection (IV a) & 9 & 8 & 1 \\
\hline & - $\quad$ Implementers/Staff (V) & 24 & 8 & 16 \\
\hline \multirow[t]{4}{*}{5.} & Assistant of general Administration (II b) & 1 & 1 & - \\
\hline & - $\quad$ Head of Division (III a) & 3 & 3 & - \\
\hline & - $\quad$ Head of subsection (IV a) & 9 & 9 & - \\
\hline & - Implementers /Staff (V) & 50 & 25 & 25 \\
\hline \multicolumn{2}{|c|}{ Amount } & 150 & 84 & 66 \\
\hline \multicolumn{2}{|c|}{ Amount for Implementing / Staff positions } & 107 & 43 & 64 \\
\hline
\end{tabular}

Source: Map of Regional Official Position in 2018

From these data it is clear that there is a significant shortage of employees when compared to the real number of existing employees. Specifically for executive positions or staff, the total number of needs is 107 (one hundred and seven) people, while the real conditions of available employees are 43 (forty-three) people so that as a whole the Regional Secretariat still needs 64 (sixty-four) employees (staff ) is new to support the implementation of basic tasks and functions in each existing work unit. The data at the same time strengthened the informant's statement stating that there was a shortage of employees in almost all work units. This condition will have a very negative effect on efforts to improve service quality at the Central Sumba District Secretariat.

Based on the results of the study it can be said that the preparation of civil servant needs in the Central Sumba Regency Secretariat is part of the implementation of policy analysis because it produces recommendations on proportional employee distribution plans following the workload of government agencies, as well as recommendations on plans for additional new employee formation through the determination of the number of needs Civil servants in every government agency. In the preparation of civil servant needs using a policy analysis methodology that includes standard systems, rules, and procedures.

This is in line with the theory that the policy analysis methodology combines standards, rules, and procedures. But standards and rules guide the selection and use of procedures and critical appraisal of the results (William N. Dunn, 1998: 20). If it is related to the results of the research, it shows that the stages of the analysis of the preparation of civil servant need carrying out by the Regional Secretariat agencies are guided by standards and rules, namely the Regulation of the Head of the Civil Service Agency Number 19 of 2011 concerning General Guidelines for Preparation of Civil Servants' Needs. The regulation is a follow-up or elaboration of Government Regulation No. 11 of 2017 concerning Management of Civil Servants, Article 11 which explains that "further provisions regarding the procedures for implementing the preparation of civil servant needs are regulated by the regulations of the Head of BKN".

While relating to procedures or stages of civil servant needs analysis, based on the Head of the Civil Service Agency Regulation No. 19 of 2011 concerning General Guidelines for Preparation of Civil Servants' Needs, stages of civil servant needs 
analysis include data and information collection, evaluation of employee needs, preparation of employee reallocation plans, and preparation of plans for additional new employee formation. Based on these stages, if related to the results of the research, it can be said that the preparation of civil servant needs within the scope of the Regional Secretariat has been carried out following applicable procedures.

Besides, the researcher also concluded that in general, the preparation of PNS needs carrying out was a process of human resource management aimed at determining the number and quality of PNS following the needs of each government agency and to realize a proportional distribution of employees in supporting workload government agencies.

However, if it is related to the analysis of the needs of civil servants at the Regional Secretariat of Central Sumba Regency, it can be said that it is not yet fully in line with the objectives of human resource management. This can be seen in several stages of the analysis which shows the gap. First, at the stage of data and information collection which shows that the number of available employees is not proportional to the needs of employees based on workload. Second, in the evaluation phase of employee needs which further confirms that there is a shortage of employees in all existing work units. This is contrary to the general objectives of human resource management started by Melayu S.P. Hasibuan (2011: 250) which states that the general objectives of human resource management are:

1. Determine the quality and quantity of employees who will fill all positions in the company;

2. Ensuring the availability of workers now and in the future;

3. Avoid misunderstandings in management and overlap in the performance of tasks;

4. Facilitate coordination so that work productivity increases; and

5. Avoiding employee shortcomings or strengths.

Based on this opinion, if it is related to the results of the research, it shows that the objectives of human resource management have not been fully realized, especially in guaranteeing the availability of manpower (PNS), present or future, and efforts to avoid employee shortages or excesses.

\subsection{Application of the results of the preparation of the needs of Civil Servants in the Regional Secretariat of Central Sumba Regency}

Preparation of the needs of Civil Servants (PNS) becomes an obligation for all government agencies to prepare competent candidates for the state apparatus with knowledge, skills and a good attitude to support government efforts in improving the quality of services to the community. One form of application of the results of the preparation of civil servant needs is to determine the national civil servant needs.

The determination of the needs of civil servants nationally is carried out based on a proposal from the Official of the Regional Institution Staffing. The main factor that is the basis for consideration in determining needs is the results of the preparation of civil servants' needs where data on the number of needs are listed based on the workload of government agencies. Besides, other supporting data must be submitted for consideration as stated in Government Regulation Number 11 the Year 2017 concerning Management of Civil Servants Article 13 letter (c), namely:

1. Institutional data;

2. The area, geographical conditions, and potential of the region to be developed;

3. The number and composition of civil servants available at each level of position;

4. The number of civil servants entering the retirement age:

5. The ratio between the number of civil servants and the total population; and

6. The ratio between the employee's budget and the overall budget.

Based on data from the research results show that the Central Sumba District Government has submitted additional proposals for the formation of new employees based on the analysis of the needs of civil servants. This is evidenced by the flow of filling the e-Formation application which includes the stages of inputting the organizational structure, input bezzeting, details of the proposed formation, and job analysis input. The input process is entirely based on the results of the preparation of civil servant needs. The number of additional proposals for the formation of new employees, especially for the Regional Secretariat, is 64 (sixty-four) people.

As a form of follow-up to the proposal, the central government issued an Announcement of the Minister of Administrative Reform and Bureaucratic Reform Number: B / 1069 / M.SM.01.00 / 2019, dated October 28, 2019, concerning Information on Acceptance of 2019 Civil Servant Candidates in the Central Government Environment and regions. The first point of the contents of the announcement is that in the fiscal year 2019 there will be open recruitment of prospective Civil Servants in 68 (sixty-eight) Ministries / Institutions and 462 (four hundred sixty-two) Provincial / Regency / City Governments. Furthermore, in the appendix to the announcement, for the local government agencies carrying out the procurement of CPNS in 2019, one of them is Central Sumba with a total allocation of 193 (one hundred ninety-three) people. Of this amount it is expected to be able to meet the employee shortages that occur, specifically at the Regional Secretariat. 
However, in the details of the allocation of formation for technical personnel based on the Central Sumba District Announcement Number: BKPP.800 / 1454 / 53.17 / XI / 2019, November 8, 2019, concerning Acceptance of Civil Servants in the fiscal year 2019, the technical staff numbered 69 (sixty-nine) people. Of these, all are formations for the Office, Agency, Inspectorate, Office, and none for the Regional Secretariat. In this condition the regional government cannot protest or intervene because the determination of the needs of civil servants is entirely under the authority of the central government. This is in line with the provisions in Government Regulation No. 11 of 2017 concerning Management of Civil Servants, Article 12 paragraph (1) explains that "the needs of civil servants nationally are determined by the Minister every year, after taking into account the minister's opinion that carries out government affairs in the financial sector and chief technical considerations BKN ". In other words, the central government is given full authority to determine the number of formations in all government agencies, while regional agencies are only given the authority to compile and determine the needs following the conditions of their respective regions.

This condition is in line with the opinion that good policy analysis is not necessarily utilized by the wearer, and even if the policy analysis is used, it does not guarantee a better policy (William N. Dunn, 1998: 29). However good the process of formulating the needs of civil servants is carried out but when the authority of the determination is still with the central government then the results of the preparation of needs that are part of the policy analysis process becomes useless.

Besides, it can also be said that the results of the determination of the needs of civil servants nationally which did not address the problem of employee shortages that occur at the Regional Secretariat are contrary to the provisions in Article 12 paragraph (7) letter b, Government Regulation Number 11 the Year 2017 concerning PNS Management which states that Determination of the needs of civil servants as referred to in paragraph (1) is based on a proposal from the Regional Institution's PPK coordinated by the Governor. Therefore it can be said that the determination of the needs of civil servants nationally is not following the proposal of the local government where the proposal has gone through a process of policy analysis to obtain recommendations on the problem of employee shortages that occur.

Responding to these conditions, the results of the study showed that to meet the needs of employees at the Regional Secretariat, an alternative policy that could be taken was to conduct the procurement/recruitment of Regional Contract Workers or who were now called as Government Employees with Work Agreements (PPPK). The PPPK recruitment process has several similarities with the procurement process that applies to civil servants. This is evidenced by the provisions contained in Government Regulation Number 49 the Year 2018 concerning Management of Government Employees with Work Agreements. In Article 4 paragraph (1) it is explained that "each Government Institution is required to draw up the needs for the number and type of PPPK positions based on a job analysis and workload analysis". And Article 4 paragraph (3) explains that "the compilation of the needs for the number of PPPK as referred to in paragraph (1) constitutes an integral part of the preparation of civil servant needs". Based on these provisions, it can be said that the procurement of PPPK is the most likely alternative policy to be taken to overcome staff shortages in the current budget year and subsequent years.

\subsection{Conclusions}

\section{CONCLUSIONS AND RECOMMENDATIONS}

Based on the data from the research and discussion results presented, several conclusions can be drawn as follows:

1. The preparation of civil servant needs in the Central Sumba Regency Secretariat is carried out based on the needs analysis stage which includes collecting data and information, evaluating employee needs, preparing employee reallocation plans, and preparing additional plans for new employee formation. The results of the analysis of the preparation of civil servant needs show that there are still a shortage of employees when compared to the total needs of employees based on the workload of government agencies, so it is necessary to propose the addition of new employee formations;

2. The determination of the needs of civil servants nationally is not entirely based on proposals submitted by local governments because the determination of the needs of civil servants is entirely the authority of the central government without any intervention from the local government so that efforts that can be made to overcome the shortcomings of civil servants are by recruiting/procuring Government Employees with an Agreement Work.

\subsection{Recommendations}

The Regional Secretariat as a government agency needs to make efforts to improve services to realize the vision and mission set. Therefore several suggestions may be of concern, namely:

1. attempt to improve the quality of the preparation of civil servant needs every year while still observing or referring to the established procedures for implementation;

2. seeks to coordinate with the Regional Government Budget Team to discuss the availability of the Regional Revenue and Expenditure Budget in the framework of civil servant procurement to meet the needs; 
3. seeks to coordinate and consult with the central government through the Ministry of Administrative Reform and Bureaucratic Reform and the National Civil Service Agency to avoid human error in the process of preparing civil servant needs;

4. Immediately prepare a Government Employee procurement plan with a Work Agreement as an alternative policy that can be taken to meet the existing employee shortages.

\section{REFERENCES}

Ardana, I Komang dkk. 2012. Manajemen Sumber Daya Manusia. Yogyakarta : Graha Ilmu.

Dunn, William N. 1998. Pengantar Analisis Kebijakan Publik Edisi Kedua. Yogyakarta:

Gadjah Mada University Press.

Elbadiansyah. 2019. Manajemen Sumber Daya Manusia. Malang: CV IRDH.

Hasibuan, Melayu S.P. 2007. Manajemen Sumber Daya Manusia Perusahaan. Bandung :

PT. Bumi Aksara.

.2011. Manajemen Sumber Daya Manusia. Jakarta : PT. Bumi Aksara.

Marwansyah, 2014. Manajemen Sumber Daya Manusia. Bandung : Alfabeta.

R. Terry, George. 2006. Prinsip-Prinsip Manajemen. Jakarta : Bumi Aksara.

Sadili, Samsuddin. 2006. Manajemen Sumber Daya Manusia. Bandung : Pustaka Setia.

Yuniarsih, Tjutju, \& Suwatno. 2008. Manajemen Sumber Daya Manusia. Bandung : Alfabeta.

Undang-Undang Nomor 5 Tahun 2014 tentang Aparatur Sipil Negara.

Peraturan Pemerintah Nomor 11 Tahun 2017 tentang Manajemen Pegawai Negeri Sipil.

Peraturan Pemerintah Nomor 49 Tahun 2018 tentang Manajemen Pegawai Pemerintah dengan Perjanjian Kerja.

Peraturan Kepala Badan Kepegawaian Negara Nomor 19 Tahun 2011 tentang Pedoman

Umum Penyusunan Kebutuhan Pegawai Negeri Sipil.

Pengumuman Menteri Pendayagunaan Aparatur Negara dan Reformasi Birokrasi Nomor:

B/1069/M.SM.01.00/2019, tanggal 28 Oktober 2019 tentang Informasi Penerimaan

Calon Pegawai Negeri Sipil Tahun 2019 di Lingkungan Pemerintah Pusat dan Daerah.

Pengumuman Bupati Sumba Tengah Nomor: BKPP.800/1454/53.17/XI/2019, tanggal 8

November 2019 tentang Penerimaan Pegawai Negeri Sipil tahun anggaran 2019 